Supporting Information

\title{
Switching of Recognition First and Reaction First Mechanisms in Host-Guest Binding Associated with Chemical Reactions
}

Yoko Sakata, Munehiro Tamiya, Masahiro Okada, and Shigehisa Akine*

* To whom correspondence should be addressed.

E-mail: akine@se.kanazawa-u.ac.jp 


\section{Experimental}

\section{Materials and methods}

Reagents and solvents were purchased from commercial sources and used without further purification. ${ }^{1} \mathrm{H}$ NMR spectra were recorded on a JEOL JNM-ECS $400(400 \mathrm{MHz})$. Chemical shifts were referenced with respect to the solvent residual peak (3.31 ppm for $\mathrm{CD}_{2} \mathrm{HOD}, 1.94 \mathrm{ppm}$ for $\mathrm{CD}_{2} \mathrm{HCN}$ ). ESI-TOF mass spectra were recorded on a Bruker Daltonics micrOTOF II.

\section{X-ray Crystallography}

Intensity data were collected on a Bruker SMART APEX II (with $\mathrm{Cu} \mathrm{K} \alpha$ radiation, $\lambda=1.54178 \AA$ ). The data were corrected for Lorentz and polarization factors and for absorption by semiempirical methods based on symmetry-equivalent and repeated reflections. The structures were solved by direct methods (SHELXT $\left.{ }^{1}\right)$ and refined by full-matrix least squares on $F^{2}$ using SHELXL 2014 ${ }^{2}$. Crystallographic data for $\left[\mathrm{LCo}_{2}(\text { pip })_{4}\right](\mathrm{OTf})_{2} \cdot 2 \mathrm{MeOH}, \quad\left[\mathrm{LCO}_{2}(\text { pip })_{2}(\mathrm{OMe})_{2} \cdot \mathrm{Na}(\mathrm{MeOH})_{2}\right](\mathrm{OTf}) \cdot 2 \mathrm{MeOH}, \quad$ and $\quad\left[\mathrm{LCo}_{2}(\mathrm{pip})_{2}(\mathrm{OMe})_{2}\right.$ $\left.\cdot \mathrm{K}(\mathrm{MeOH})_{2}\right](\mathrm{OTf}) \cdot 2.5 \mathrm{MeOH} \cdot \mathrm{Et}_{2} \mathrm{O}$ have been deposited with the Cambridge Crystallographic Data Centre under reference number CCDC 1863167-1863169, respectively. These data can be obtained free of charge via www.ccdc.cam.ac.uk/data_request/cif (or from the Cambridge Crystallographic Data Centre, 12 Union Road, Cambridge CB2 1EZ, UK).

\section{Synthesis of $\left[\mathrm{LCo}_{2}(\mathrm{pip})_{4}\right](\mathrm{OTf})_{2}$}

A solution of macrocyclic ligand $\mathrm{H}_{4} \mathrm{~L}(148 \mathrm{mg}, 0.200 \mathrm{mmol})^{3}$ in chloroform $(40 \mathrm{~mL})$ was mixed with a solution of cobalt(II) acetate tetrahydrate $(108 \mathrm{mg}, 0.440 \mathrm{mmol})$ in methanol $(6 \mathrm{~mL})$, tetrabutylammonium trifluoromethanesulfonate $(392 \mathrm{mg}, 1.00 \mathrm{mmol})$ in methanol $(6 \mathrm{~mL})$, and piperidine $(236 \mu \mathrm{L}, 2.4 \mathrm{mmol})$ and stirred under air for $15 \mathrm{~h}$. The solution was filtered and the filtrate was concentrated to dryness. The residue was dissolved in methanol $(3 \mathrm{~mL})$ containing piperidine $(118 \mu \mathrm{L}, 1.2 \mathrm{mmol})$. Diethyl ether was then added and the precipitate was collected by filtration. After repeating the purification procedure, the precipitate was collected by filtration to obtain $\left[\mathrm{LCo}_{2}(\text { pip })_{4}\right](\mathrm{OTf})_{2}(217 \mathrm{mg} .0 .150 \mathrm{mmol}, 75 \%)$ as reddish brown powder, ${ }^{1} \mathrm{H}$ NMR (400 MHz, $\left.\mathrm{CD}_{3} \mathrm{CN}\right) \delta 8.58(\mathrm{~s}, 4 \mathrm{H}), 8.19-8.17(\mathrm{~m}, 4 \mathrm{H}), 7.62-7.60(\mathrm{~m}, 4 \mathrm{H}), 7.49(\mathrm{~d}, J=7.3 \mathrm{~Hz}, 4 \mathrm{H})$, $7.32(\mathrm{~d}, J=7.3 \mathrm{~Hz}, 4 \mathrm{H}), 6.76(\mathrm{t}, J=7.3 \mathrm{~Hz}, 4 \mathrm{H}), 3.06-3.01(\mathrm{~m}, 4 \mathrm{H}), 2.72-2.69(\mathrm{~m}, 8 \mathrm{H}), 1.80-1.70(\mathrm{~m}, 8 \mathrm{H})$, $1.42-1.33(\mathrm{~m}, 12 \mathrm{H}), 1.19-0.96(\mathrm{~m}, 12 \mathrm{H})$; ESI-MS $\mathrm{m} / \mathrm{z} 1263.4\left[\mathrm{LCo}_{2}(\mathrm{pip})_{4}+\mathrm{OTf}^{+}\right.$. Anal. Calcd for $\mathrm{C}_{62} \mathrm{H}_{68} \mathrm{Co}_{2} \mathrm{~F}_{6} \mathrm{~N}_{8} \mathrm{O}_{12} \mathrm{~S}_{2} \cdot 2 \mathrm{H}_{2} \mathrm{O}: \mathrm{C}, 51.38 ; \mathrm{H}, 5.01 ; \mathrm{N}, 7.73$. Found: C, 51.57; H, 4.88; N, 7.71.

\section{Determination of rate constants.}

The sample solutions were prepared by introducing a solution of $\left[\mathrm{LCo}_{2}(\mathrm{pip})_{4}\right](\mathrm{OTf})_{2}$ in $\mathrm{CD}_{3} \mathrm{OD}(1.0 \mathrm{mM})$ into a sample tube containing the required amount of $\mathrm{M}(\mathrm{OTf})(\mathrm{M}=\mathrm{Na}, \mathrm{K}, \mathrm{Rb})$. The time dependence of the mole fractions of each species at $298 \mathrm{~K}$ was determined by ${ }^{1} \mathrm{H}$ NMR integrals. The simulated mole fractions were calculated by numerical integration methods with $d t=0.1 \mathrm{~min}$ step and the least-squares regression was 
performed by Solver Add-In in Microsoft Excel. The standard deviations of rate constants $(\Delta k)$ were estimated as $(\Delta k)^{2}=\Sigma\left(\left(\partial k / \partial x_{i}\right)^{2}\left(\Delta x_{i}\right)^{2}\right)$ where the partial differentials $\partial k / \partial x_{i}$ are numerically determined and the average deviation of the regression $\Delta x_{\mathrm{av}}\left(=\left|\delta_{\mathrm{obs}}-\delta_{\mathrm{fit}}\right|\right)$ was used as $\Delta x_{i}$ for each of the observed data. The initial rates, $k_{\text {ini, }}$, were determined by the linear regression of the first $4-8$ points. 
${ }^{1} \mathrm{H}$ NMR spectra of $\left[\mathrm{LCo}_{2}(\mathrm{pip})_{4}\right](\mathrm{OTf})_{2}$

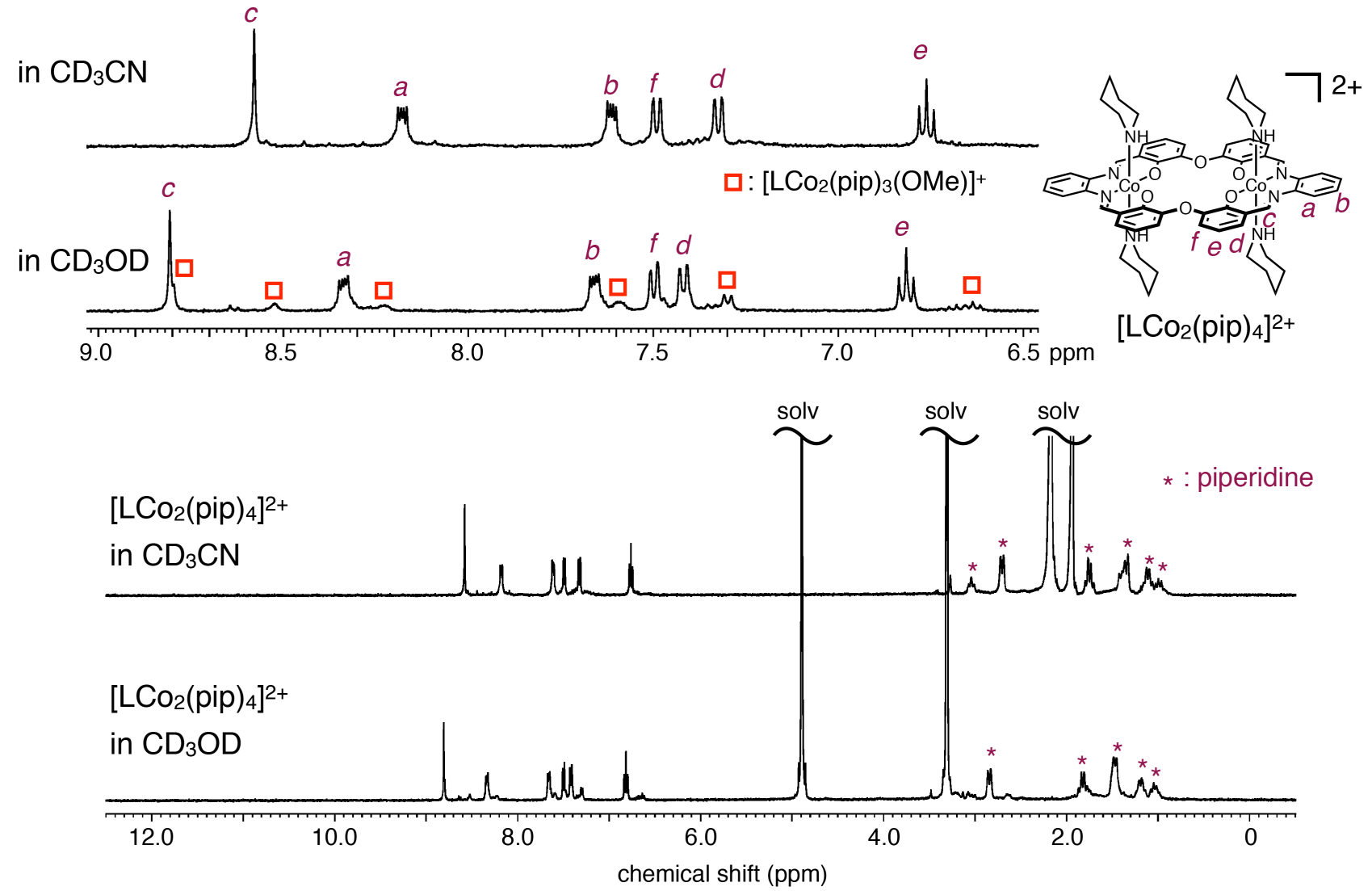

Figure S1. ${ }^{1} \mathrm{H}$ NMR spectra of $\left[\mathrm{LCo}_{2}(\text { pip })_{4}\right](\mathrm{OTf})_{2}$ in $\mathrm{CD}_{3} \mathrm{CN}$ (upper) and $\mathrm{CD}_{3} \mathrm{OD}$ (lower, 5.5 min after dissolution). 
ESI-TOF mass spectra of $\quad\left[\mathrm{LCo}_{2}(\mathrm{pip})_{4}\right](\mathrm{OTf})_{2}, \quad\left[\mathrm{LCo}_{2}(\mathrm{pip})_{2}(\mathrm{OMe})_{2}\right], \quad$ and $\left[\mathrm{LCo}_{2}(\text { pip })_{2}(\mathrm{OMe})_{2} \bullet \mathrm{Na}\right](\mathrm{OTf})$

(b)

$\left[\mathrm{LCo}_{2}(\text { pip })_{2}(\mathrm{OMe})_{2}+\mathrm{H}\right]^{+}$

$\left[\mathrm{LCo}_{2}(\mathrm{pip})_{2}(\mathrm{OMe})_{2}+\mathrm{Na}\right]^{+} \quad$ upper: theoretical
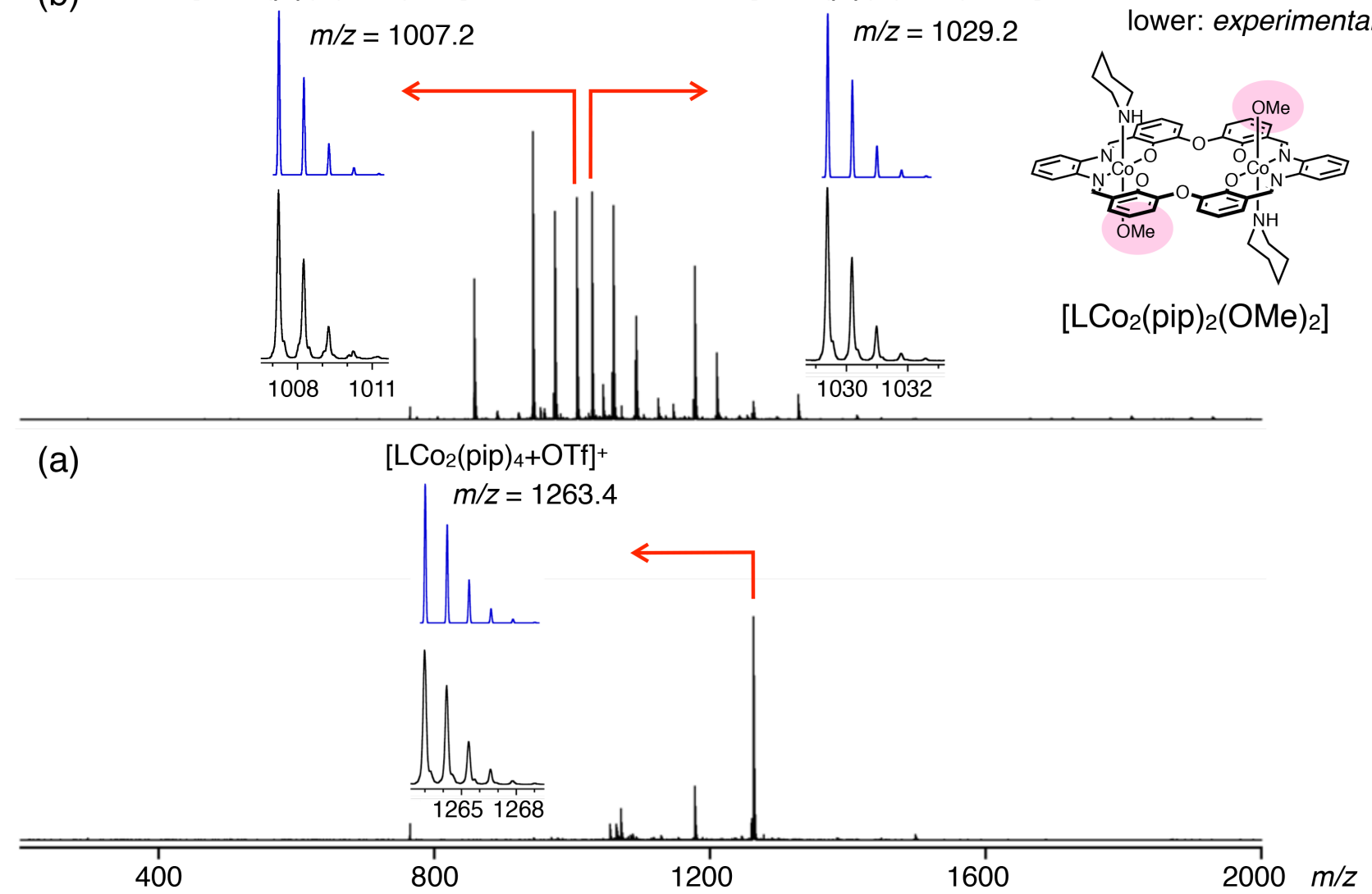

lower: experimental

Figure S2. ESI-TOF mass spectra of $\left[\mathrm{LCo}_{2}(\mathrm{pip})_{4}\right](\mathrm{OTf})_{2}$ (a) recorded immediately after dissolution in methanol and (b) recorded after $20 \mathrm{~h}$ at room temperature, showing the peaks assignable to $\left[\mathrm{LCo}_{2}(\text { pip })_{4}(\mathrm{OMe})_{2}\right]$. 


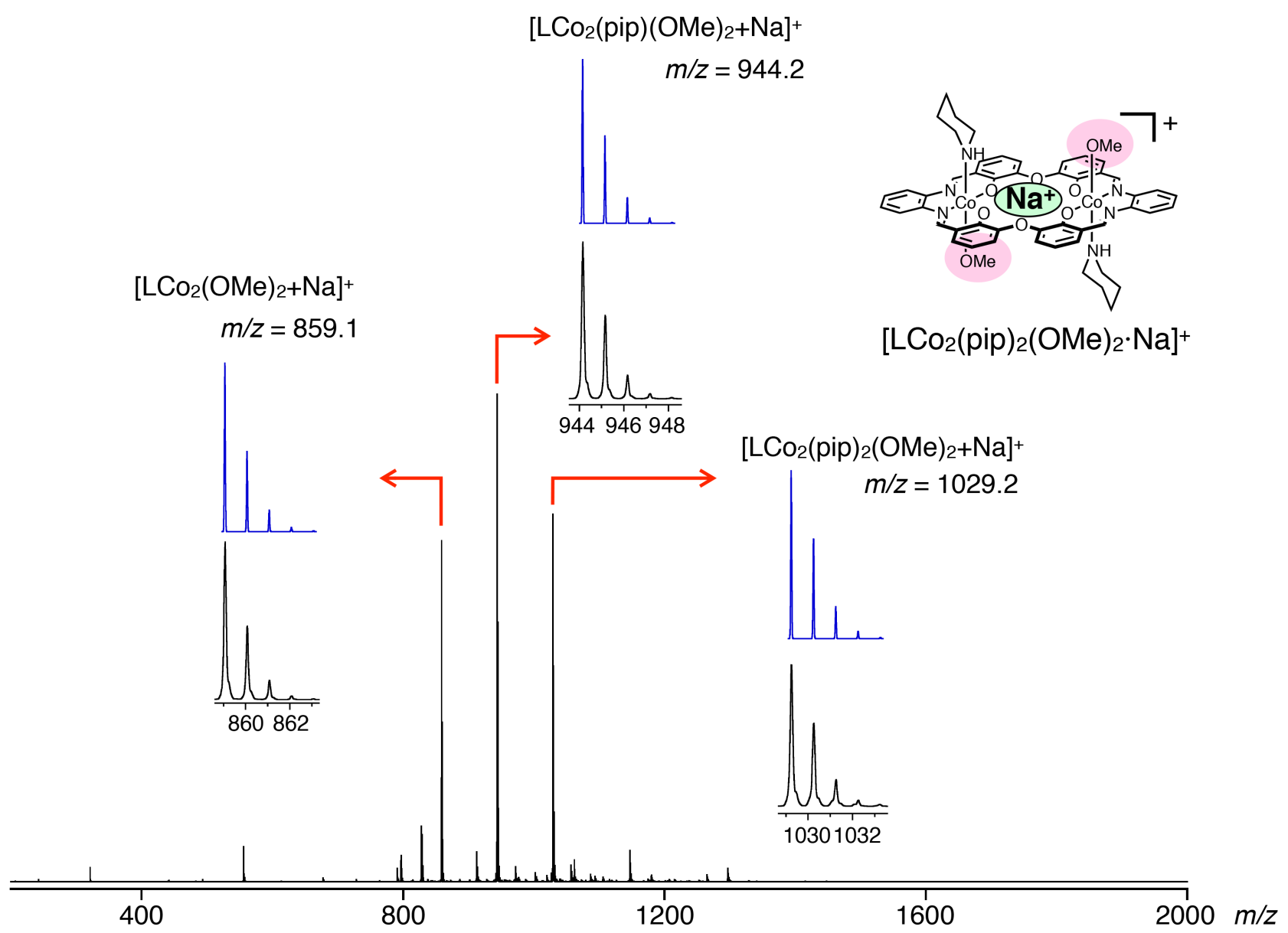

Figure S3. ESI-TOF mass spectrum of $\left[\mathrm{LCo}_{2}(\mathrm{pip})_{4}\right](\mathrm{OTf})_{2}$ after the solvolysis in methanol in the presence of $\mathrm{NaOTf}$, showing the peaks assignable to $\left[\mathrm{LCo}_{2}(\text { pip })_{2}(\mathrm{OMe})_{2} \bullet \mathrm{Na}\right](\mathrm{OTf})$. 
Crystallographic data for $\left[\mathrm{LCo}_{2}(\text { pip })_{4}\right](\mathrm{OTf})_{2} \bullet 2 \mathrm{MeOH},\left[\mathrm{LCo}_{2}(\mathrm{pip})_{2}(\mathrm{OMe})_{2} \bullet \mathrm{Na}(\mathrm{MeOH})_{2}\right](\mathrm{OTf})$ $\bullet 2 \mathrm{MeOH}$, and $\left[\mathrm{LCo}_{2}(\mathrm{pip})_{2}(\mathrm{OMe})_{2} \cdot \mathrm{K}(\mathrm{MeOH})_{2}\right](\mathrm{OTf}) \cdot 2.5 \mathrm{MeOH} \cdot \mathrm{Et}_{2} \mathrm{O}$

Table S1. Crystallographic data of $\left[\mathrm{LCo}_{2}(\text { pip })_{4}\right](\mathrm{OTf})_{2} \cdot 2 \mathrm{MeOH}$ and $\left[\mathrm{LCo}_{2}(\text { pip })_{2}(\mathrm{OMe})_{2} \cdot \mathrm{Na}(\mathrm{MeOH})_{2}\right](\mathrm{OTf})$ - $2 \mathrm{MeOH}$.

\begin{tabular}{|c|c|c|}
\hline & {$\left[\mathrm{LCo}_{2}(\text { pip })_{4}\right](\mathrm{OTf})_{2} \cdot 2 \mathrm{MeOH}$} & {$\left[\mathrm{LCo}_{2}(\text { pip })_{2}(\mathrm{OMe})_{2} \bullet \mathrm{Na}(\mathrm{MeOH})_{2}\right](\mathrm{OTf}) \cdot 2 \mathrm{MeOH}$} \\
\hline Formula & $\mathrm{C}_{64} \mathrm{H}_{76} \mathrm{Co}_{2} \mathrm{~F}_{6} \mathrm{~N}_{8} \mathrm{O}_{14} \mathrm{~S}_{2}$ & $\mathrm{C}_{57} \mathrm{H}_{68} \mathrm{Co}_{2} \mathrm{~F}_{3} \mathrm{~N}_{6} \mathrm{NaO}_{15} \mathrm{~S}$ \\
\hline Formula weight & 1477.30 & 1307.08 \\
\hline Temperature (K) & 93 & 90 \\
\hline Crystal size $\left(\mathrm{mm}^{3}\right)$ & $0.27 \times 0.14 \times 0.03$ & $0.34 \times 0.03 \times 0.02$ \\
\hline Crystal system & triclinic & monoclinic \\
\hline Space group & $P-1$ & $C 2 / c$ \\
\hline$a(\AA)$ & $10.1370(7)$ & $20.5672(12)$ \\
\hline$b(\AA)$ & $11.5336(8)$ & $15.4382(9)$ \\
\hline$c(\AA)$ & $16.1693(11)$ & $19.5237(10)$ \\
\hline$\alpha(\operatorname{deg})$ & $72.752(4)$ & 90 \\
\hline$\beta(\operatorname{deg})$ & $71.808(4)$ & $106.945(4)$ \\
\hline$\gamma(\operatorname{deg})$ & $70.200(4)$ & 90 \\
\hline$V\left(\AA^{3}\right)$ & $1650.9(2)$ & $5930.0(6)$ \\
\hline$Z$ & 1 & 4 \\
\hline$D_{\text {calcd }}\left(\mathrm{g} \mathrm{cm}^{-3}\right)$ & 1.486 & 1.464 \\
\hline Collected reflections & 12529 & 22098 \\
\hline Unique reflections & 5759 & 5301 \\
\hline$R_{\text {int }}$ & 0.0395 & 0.0731 \\
\hline $2 \theta_{\max }$ & 133.68 & 134.284 \\
\hline$F_{000}$ & 768 & 2720 \\
\hline$\mu(\mathrm{CuK} \alpha)$ & 5.280 & 5.475 \\
\hline \multirow[t]{3}{*}{ Limiting indices } & $-12 \leq h \leq 12$ & $-24 \leq h \leq 24$ \\
\hline & $-11 \leq k \leq 13$ & $-18 \leq k \leq 18$ \\
\hline & $-19 \leq l \leq 19$ & $-21 \leq l \leq 23$ \\
\hline Restraints/parameters & $0 / 435$ & $53 / 450$ \\
\hline Goodness of fit $\left(F^{2}\right)$ & 1.035 & 1.042 \\
\hline$R 1(I>2 \sigma(I))$ & 0.0508 & 0.0588 \\
\hline$w R 2(I>2 \sigma(I))$ & 0.1302 & 0.1518 \\
\hline$R 1$ (all data) & 0.0594 & 0.0805 \\
\hline$w R 2$ (all data) & 0.1357 & 0.1661 \\
\hline
\end{tabular}


Table S2. Crystallographic data for $\left[\mathrm{LCo}_{2}(\text { pip })_{2}(\mathrm{OMe})_{2} \cdot \mathrm{K}(\mathrm{MeOH})_{2}\right](\mathrm{OTf}) \cdot 2.5 \mathrm{MeOH} \cdot \mathrm{Et}_{2} \mathrm{O}$.

\begin{tabular}{|c|c|}
\hline & {$\left[\mathrm{LCo}_{2}(\text { pip })_{2}(\mathrm{OMe})_{2} \cdot \mathrm{K}(\mathrm{MeOH})_{2}\right](\mathrm{OTf}) \cdot 2.5 \mathrm{MeOH} \cdot \mathrm{Et}_{2} \mathrm{O}$} \\
\hline Formula & $\mathrm{C}_{61.5} \mathrm{H}_{80} \mathrm{Co}_{2} \mathrm{~F}_{3} \mathrm{KN}_{6} \mathrm{O}_{16.5} \mathrm{~S}$ \\
\hline Formula weight & 1413.33 \\
\hline Temperature (K) & 90 \\
\hline Crystal size $\left(\mathrm{mm}^{3}\right)$ & $0.20 \times 0.13 \times 0.09$ \\
\hline Crystal system & monoclinic \\
\hline Space group & $C 2 / c$ \\
\hline$a(\AA)$ & $30.9242(9)$ \\
\hline$b(\AA)$ & $13.3451(4)$ \\
\hline$c(\AA)$ & $16.9298(5)$ \\
\hline$\alpha(\mathrm{deg})$ & 90 \\
\hline$\beta(\operatorname{deg})$ & $108.8460(10)$ \\
\hline$\gamma(\operatorname{deg})$ & 90 \\
\hline$V\left(\AA^{3}\right)$ & $6612.1(3)$ \\
\hline$Z$ & 4 \\
\hline$D_{\text {caled }}\left(\mathrm{g} \mathrm{cm}^{-3}\right)$ & 1.420 \\
\hline Collected reflections & 25810 \\
\hline Unique reflections & 6398 \\
\hline$R_{\text {int }}$ & 0.0445 \\
\hline $2 \theta_{\max }$ & 142.126 \\
\hline$F_{000}$ & 2956 \\
\hline$\mu(\mathrm{CuK} \alpha)$ & 5.463 \\
\hline \multirow[t]{3}{*}{ Limiting indices } & $-37 \leq h \leq 37$ \\
\hline & $-16 \leq k \leq 16$ \\
\hline & $-20 \leq l \leq 19$ \\
\hline Restraints/parameters & $135 / 495$ \\
\hline Goodness of fit $\left(F^{2}\right)$ & 1.039 \\
\hline$R 1(I>2 \sigma(I))$ & 0.0718 \\
\hline$w R 2(I>2 \sigma(I))$ & 0.1934 \\
\hline$R 1$ (all data) & 0.0843 \\
\hline$w R 2$ (all data) & 0.2059 \\
\hline
\end{tabular}




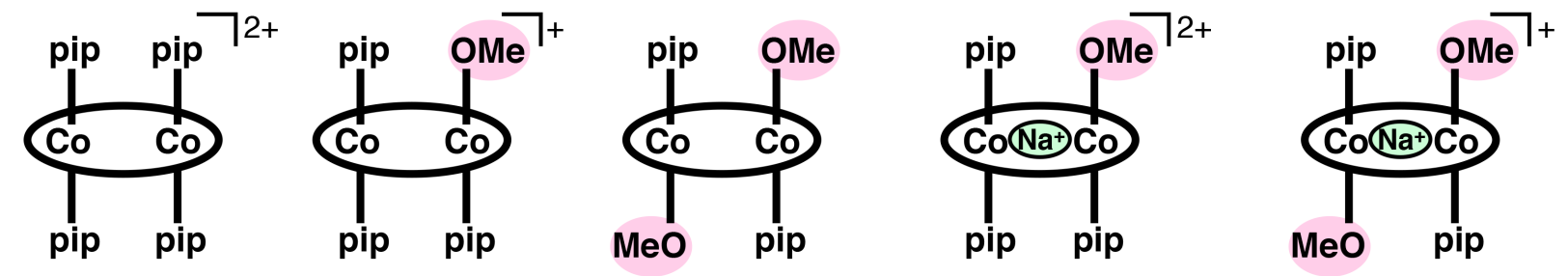

$\diamond\left[\mathrm{LCO}_{2}(\mathrm{pip})_{4}\right]^{2+} \quad \square\left[\mathrm{LCO}_{2}(\mathrm{pip})_{3}(\mathrm{OMe})\right]^{+} \Delta\left[\mathrm{LCO}_{2}(\text { pip })_{2}(\mathrm{OMe})_{2}\right] \quad \square\left[\mathrm{LCO}_{2}(\mathrm{pip})_{3}(\mathrm{OMe}) \cdot \mathrm{Na}\right]^{2+} \boldsymbol{\Delta}\left[\mathrm{LCO}_{2}(\mathrm{pip})_{2}(\mathrm{OMe})_{2} \cdot \mathrm{Na}\right]^{+}$

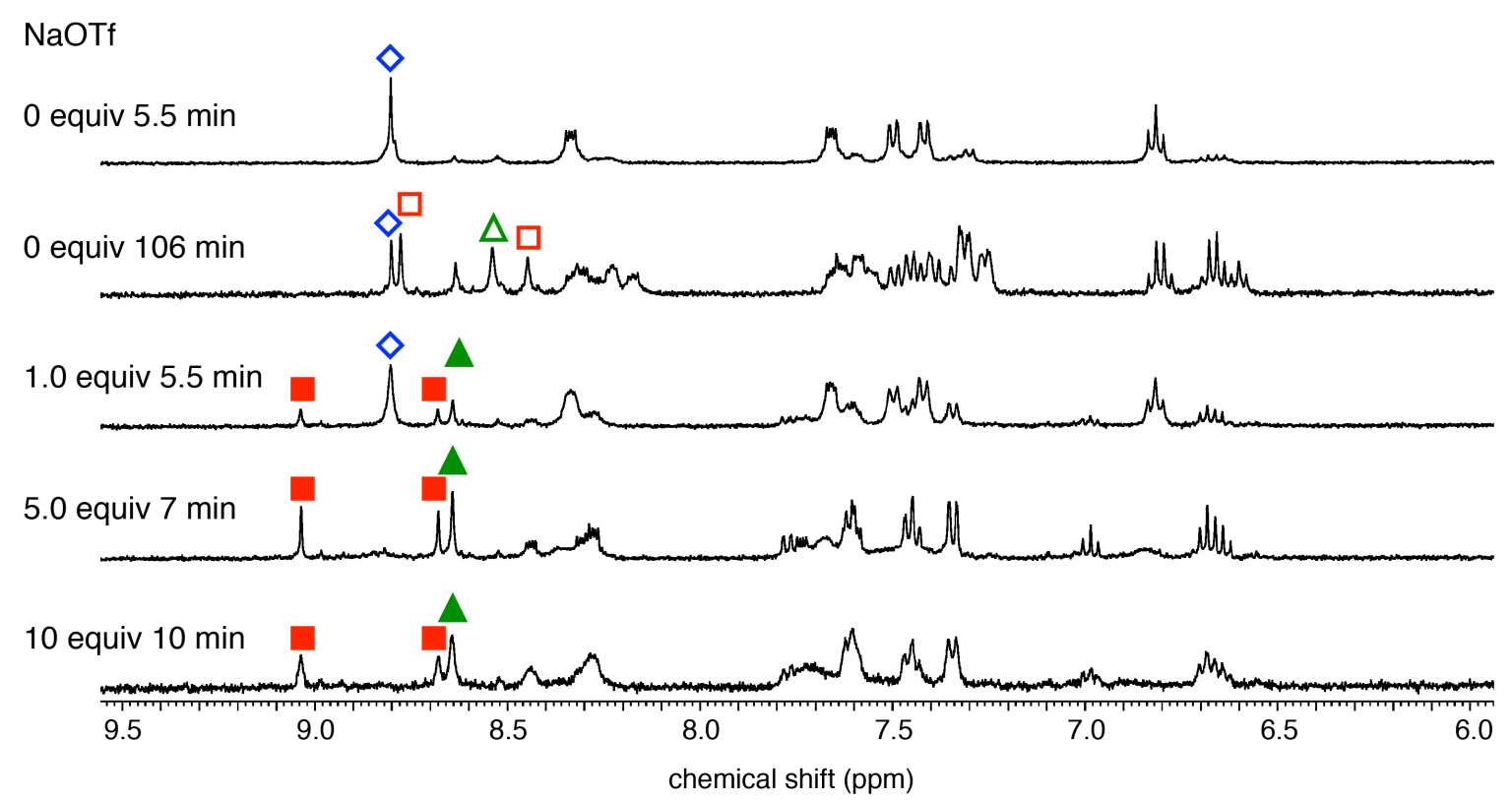

Figure S4. Comparison of ${ }^{1} \mathrm{H}$ NMR spectra of the mono-substituted complexes in the absence/presence of NaOTf. 
(a)
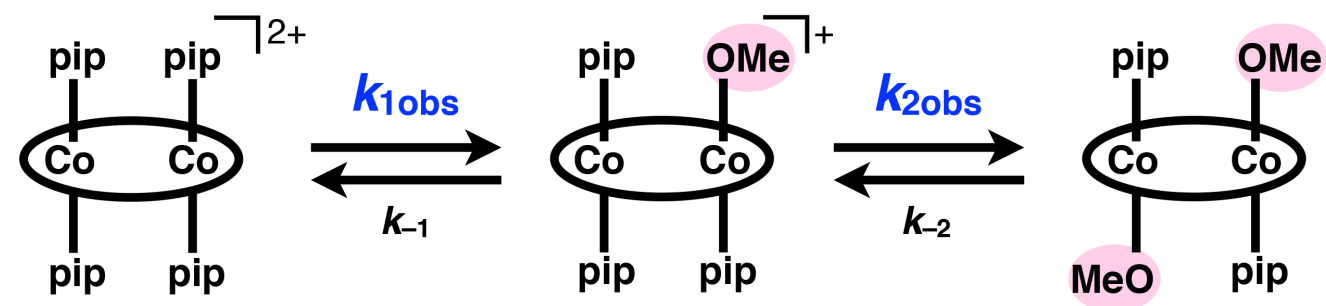

$\diamond\left[\mathrm{LCo}_{2}(\mathrm{pip})_{4}\right]^{2+}$

口[LCo 2 (pip) $\left.)_{3}(\mathrm{OMe})\right]^{+}$

$\Delta\left[\mathrm{LCO}_{2}(\mathrm{pip})_{2}(\mathrm{OMe})_{2}\right]$

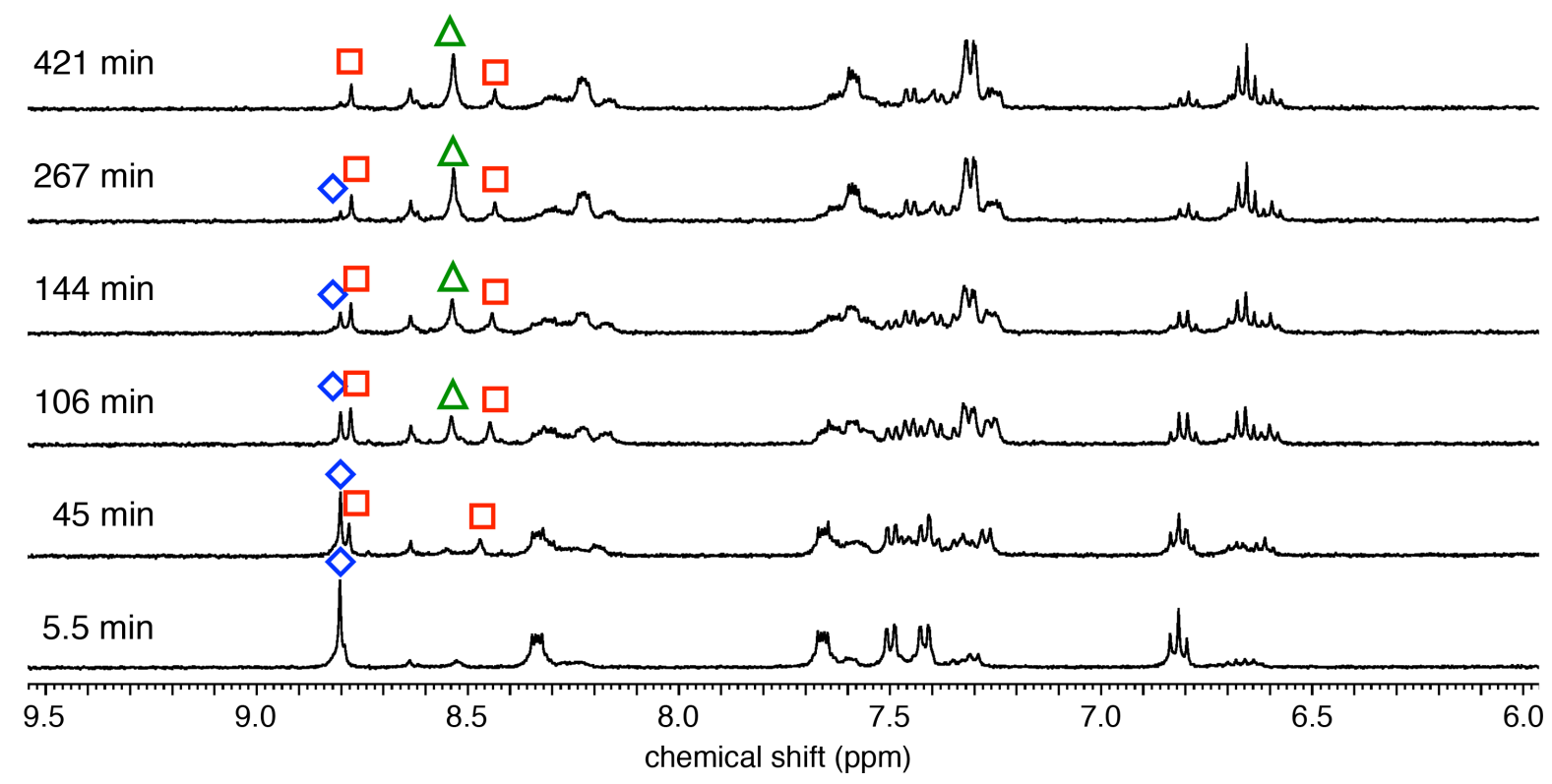

(b)

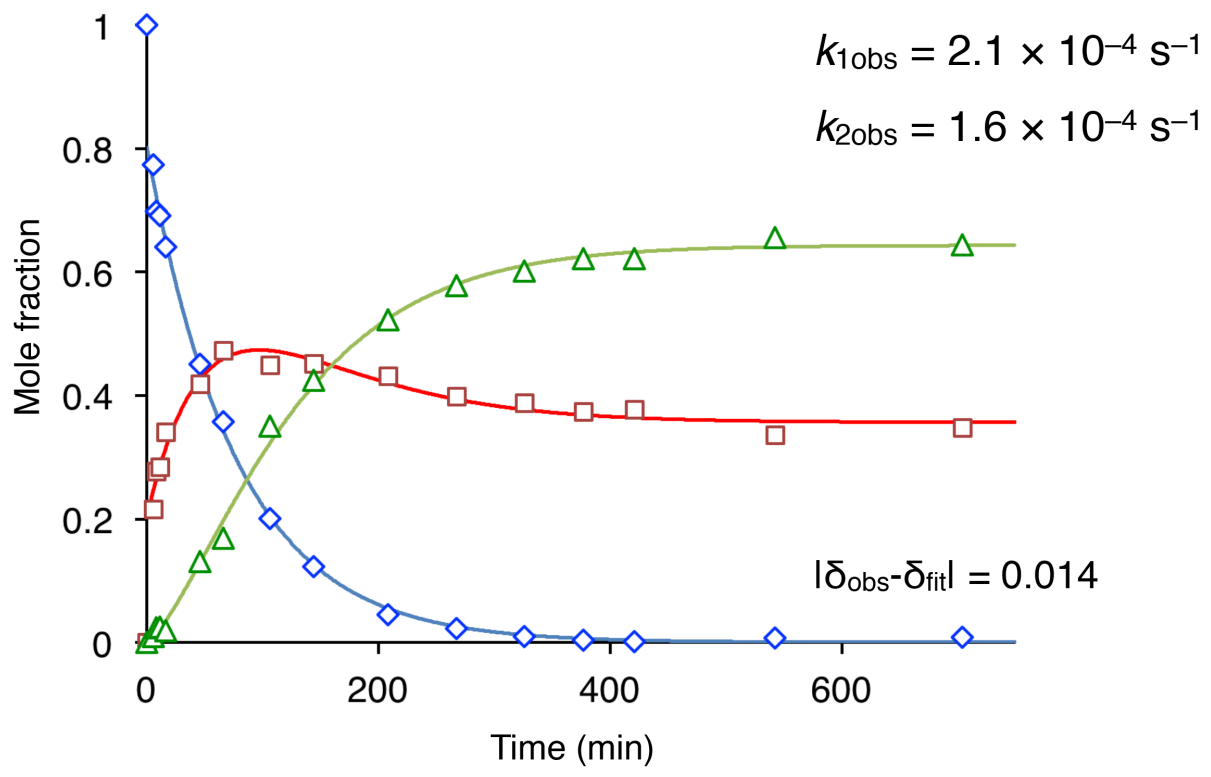

Figure S5. Time-course analysis of ligand exchange of piperidine with methoxo ligands in the absence of NaOTf. (a) ${ }^{1} \mathrm{H}$ NMR spectral changes (imine and aromatic protons) in the absence of NaOTf (blue diamonds, $\left[\mathrm{LCo}_{2}(\text { pip })_{4}\right]^{2+}$; red squares, $\left[\mathrm{LCo}_{2}(\text { pip })_{3}(\mathrm{OMe})\right]^{+}$; green triangles, $\left.\left[\mathrm{LCO}_{2}(\mathrm{pip})_{2}(\mathrm{OMe})_{2}\right]\right)$. (b) Plots of the mole fractions of the three components versus time after dissolution in $\mathrm{CD}_{3} \mathrm{OD}$. 
(a)

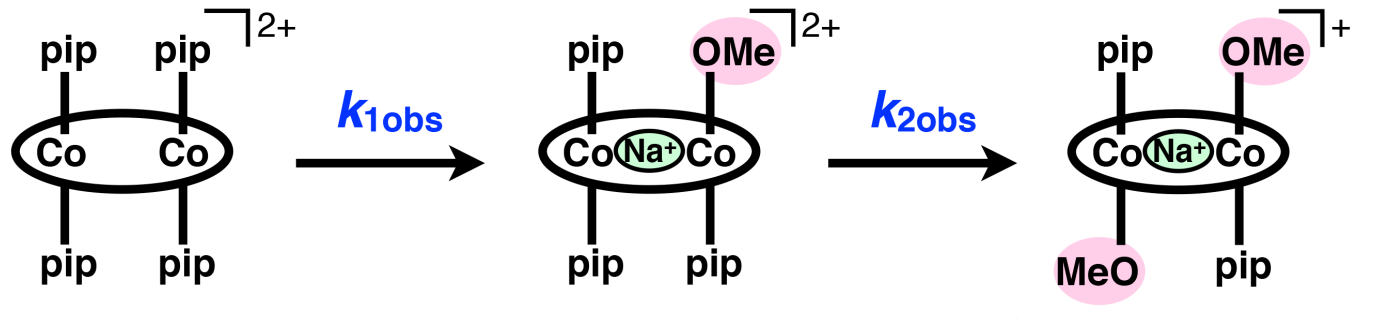

$\diamond\left[\mathrm{LCo}_{2}(\mathrm{pip})_{4}\right]^{2+}$

$\left[\mathrm{LCO}_{2}(\mathrm{pip})_{3}(\mathrm{OMe}) \cdot \mathrm{Na}\right]^{2+}$

$\Delta\left[\mathrm{LCO}_{2}(\mathrm{pip})_{2}(\mathrm{OMe})_{2} \cdot \mathrm{Na}\right]^{+}$

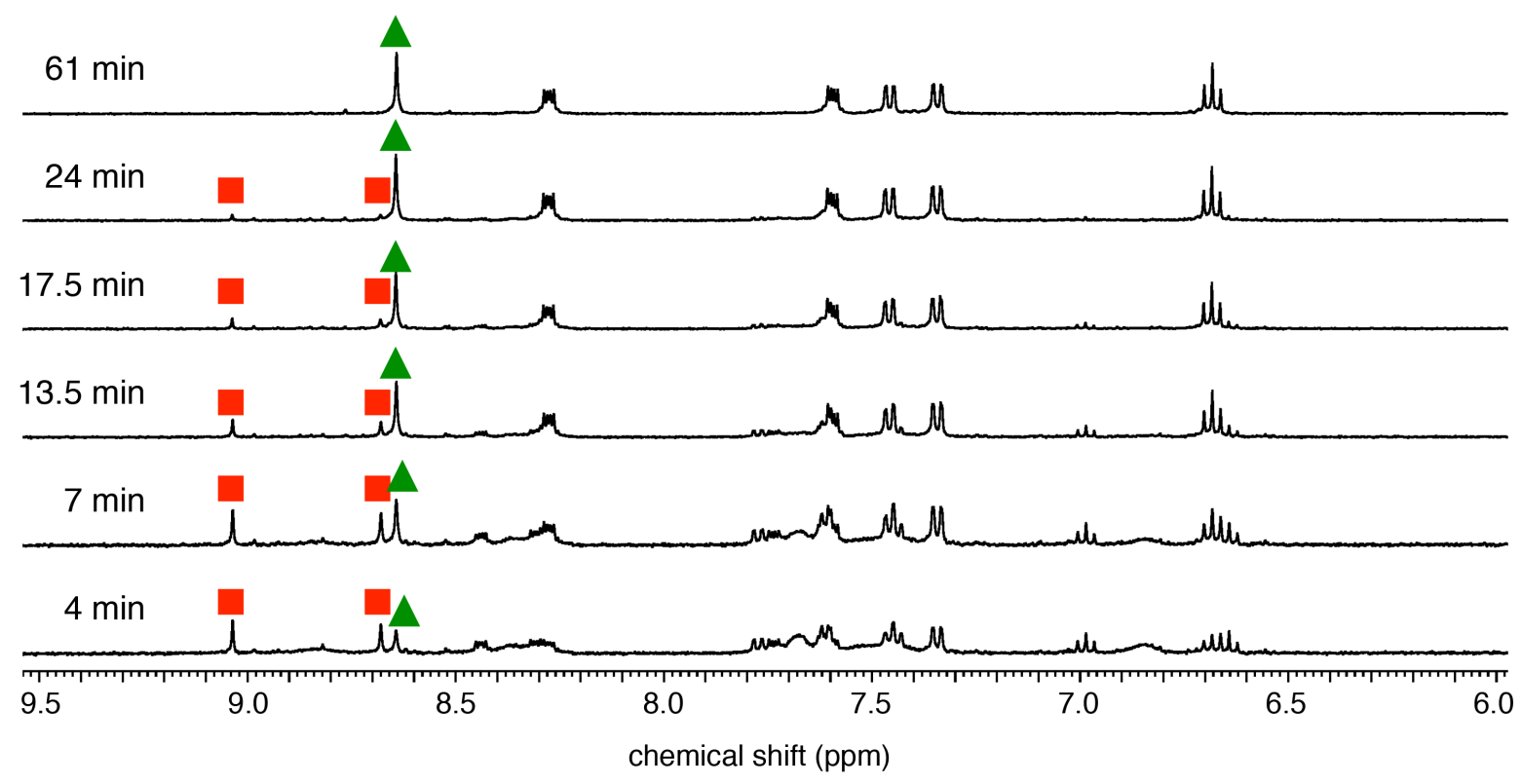

(b)

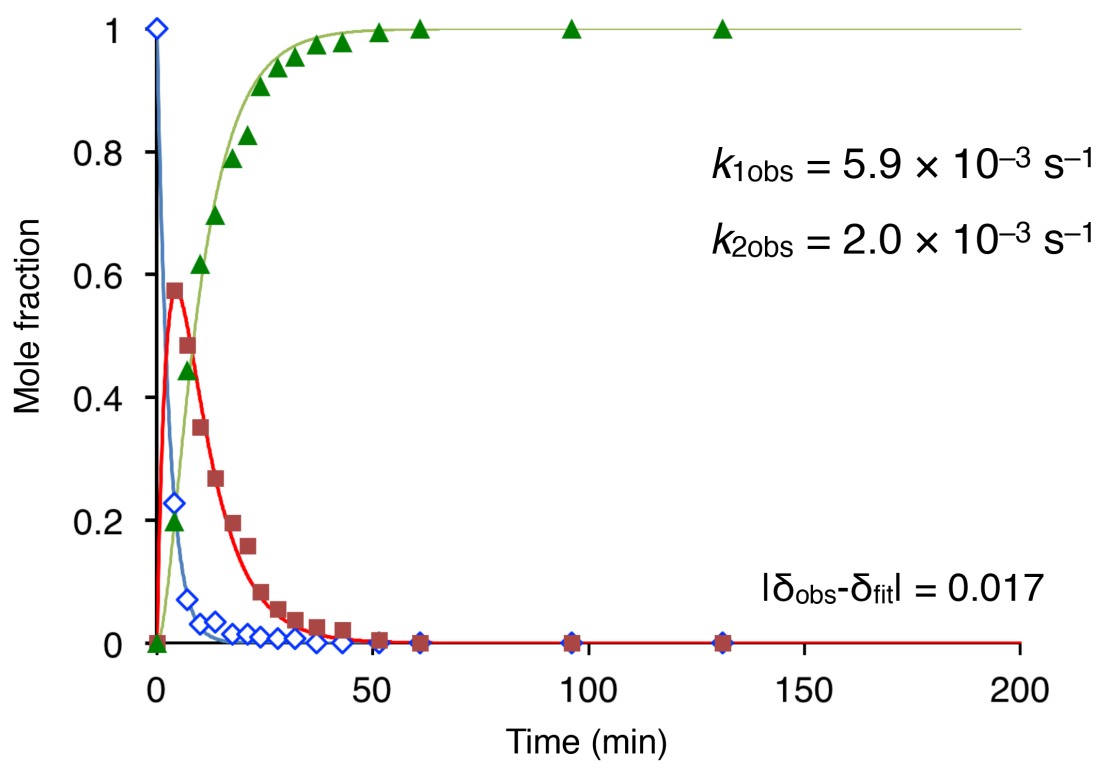

Figure S6. Time-course analysis of ligand exchange of piperidine with methoxo ligands in the presence of 5.0 equiv of NaOTf. (a) ${ }^{1} \mathrm{H}$ NMR spectral changes (imine and aromatic protons) in the presence of 5.0 equiv of NaOTf (blue diamonds, $\left[\mathrm{LCo}_{2}(\text { pip })_{4}\right]^{2+}$; red squares, $\left[\mathrm{LCo}_{2}(\mathrm{pip})_{3}(\mathrm{OMe}) \cdot \mathrm{Na}\right]^{2+}$; green triangles, $\left.\left[\mathrm{LCo}_{2}(\mathrm{pip})_{2}(\mathrm{OMe})_{2} \cdot \mathrm{Na}\right]^{+}\right)$. (b) Plots of the mole fractions of the three components versus time after dissolution in $\mathrm{CD}_{3} \mathrm{OD}$. 

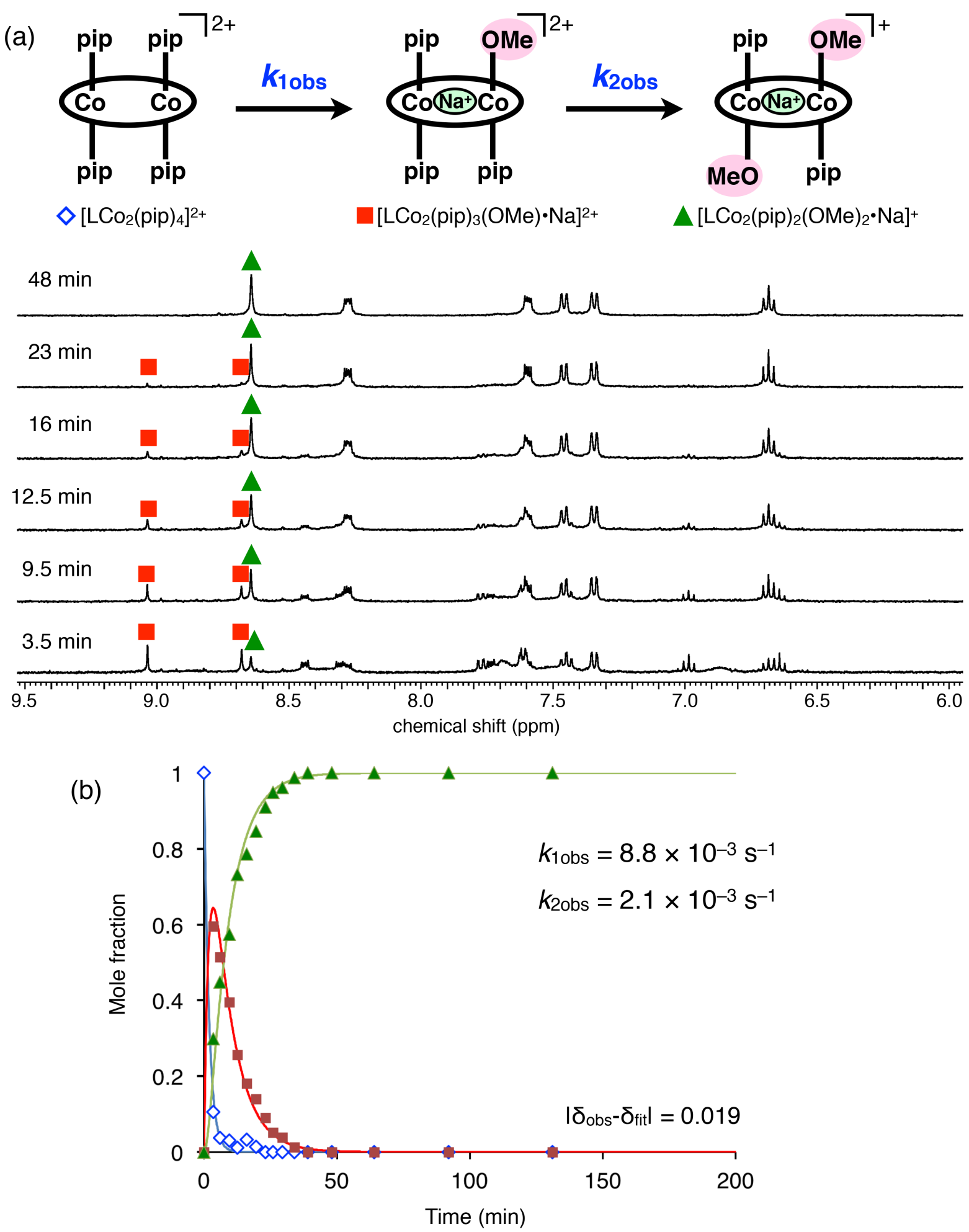

Figure S7. Time-course analysis of ligand exchange of piperidine with methoxo ligands in the presence of 7.5 equiv of NaOTf. (a) ${ }^{1} \mathrm{H}$ NMR spectral changes (imine and aromatic protons) in the presence of 7.5 equiv of $\mathrm{NaOTf}$ (blue diamonds, $\left[\mathrm{LCO}_{2}(\text { pip })_{4}\right]^{2+}$; red squares, $\left[\mathrm{LCO}_{2}(\text { pip })_{3}(\mathrm{OMe}) \cdot \mathrm{Na}\right]^{2+}$; green triangles, $\left.\left[\mathrm{LCo}_{2}(\text { pip })_{2}(\mathrm{OMe})_{2} \bullet \mathrm{Na}\right]^{+}\right)$. (b) Plots of the mole fractions of the three components versus time after dissolution in $\mathrm{CD}_{3} \mathrm{OD}$. 
(a)
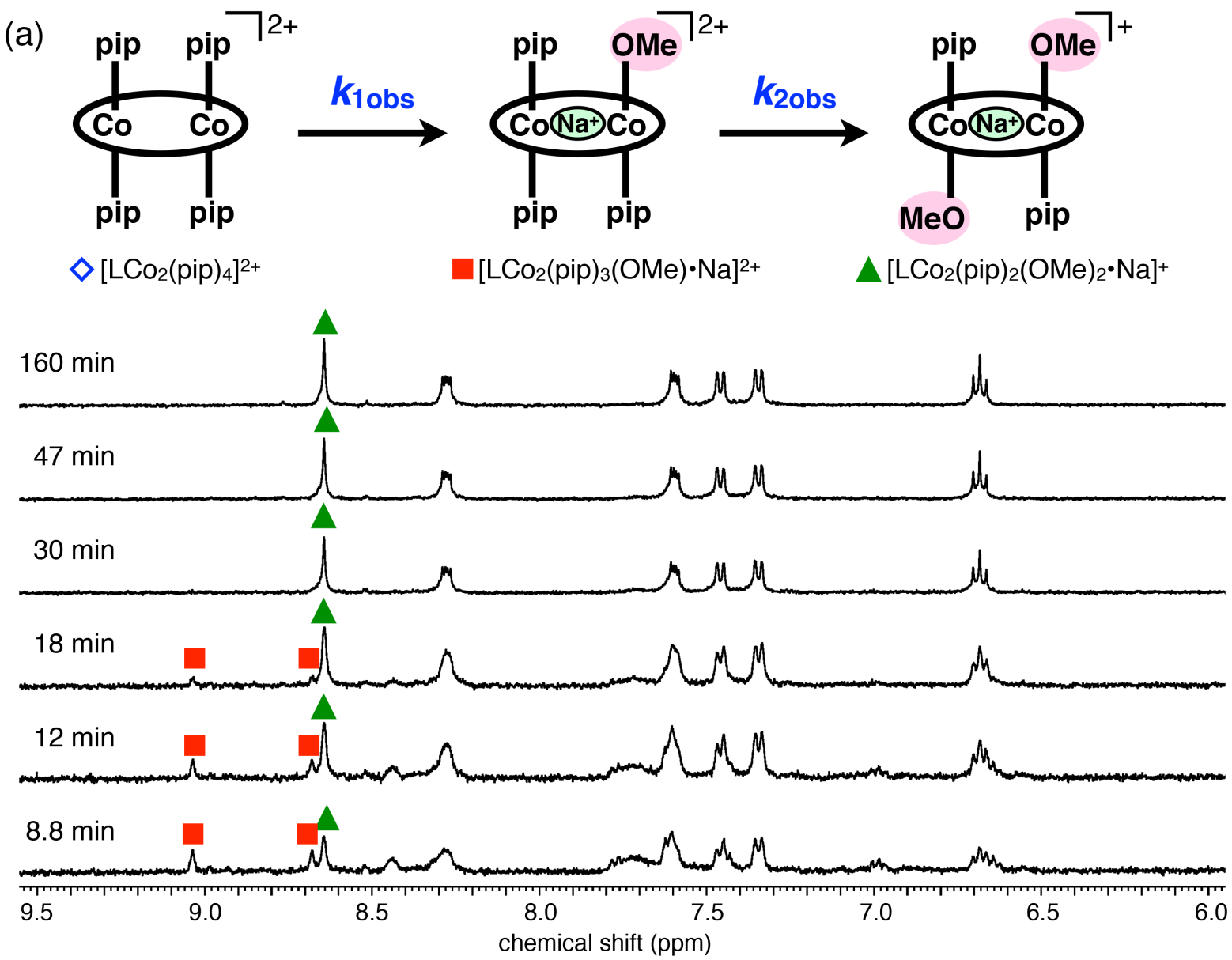

(b)

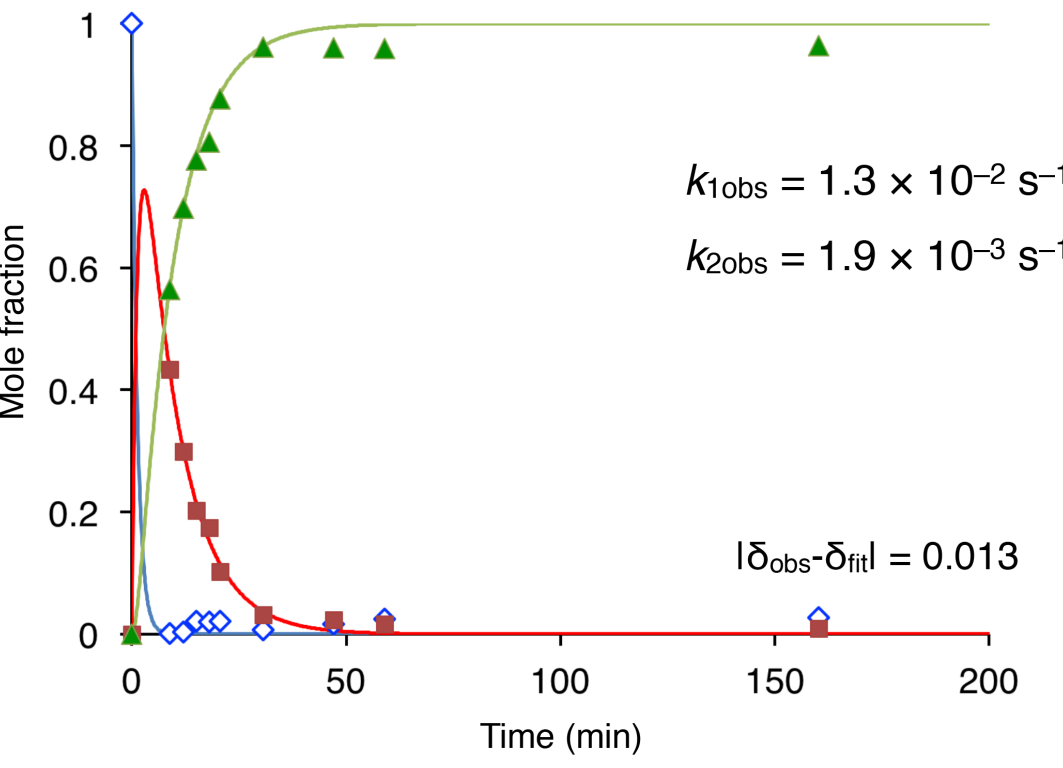

Figure S8. Time-course analysis of ligand exchange of piperidine with methoxo ligands in the presence of 10 equiv of NaOTf. (a) ${ }^{1} \mathrm{H}$ NMR spectral changes (imine and aromatic protons) in the presence of 10 equiv of NaOTf (blue diamonds, $\left[\mathrm{LCo}_{2}(\text { pip })_{4}\right]^{2+}$; red squares, $\left[\mathrm{LCo}_{2}(\mathrm{pip})_{3}(\mathrm{OMe}) \cdot \mathrm{Na}\right]^{2+}$; green triangles, $\left.\left[\mathrm{LCo}_{2}(\mathrm{pip})_{2}(\mathrm{OMe})_{2} \cdot \mathrm{Na}\right]^{+}\right)$. (b) Plots of the mole fractions of the three components versus time after dissolution in $\mathrm{CD}_{3} \mathrm{OD}$. 

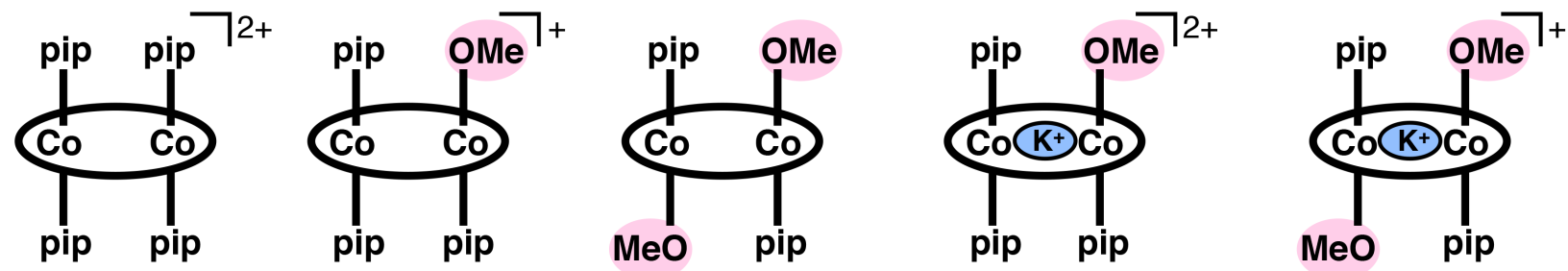

$\diamond\left[\mathrm{LCo}_{2}(\mathrm{pip})_{4}\right]^{2+} \quad \square\left[\mathrm{LCo}_{2}(\mathrm{pip})_{3}(\mathrm{OMe})\right]^{+} \Delta\left[\mathrm{LCo}_{2}(\mathrm{pip})_{2}(\mathrm{OMe})_{2}\right] \quad \square\left[\mathrm{LCo}_{2}(\mathrm{pip})_{3}(\mathrm{OMe})^{\cdot K}\right]^{2+}$

$\left[\mathrm{LCo}_{2}(\mathrm{pip})_{2}(\mathrm{OMe})_{2} \cdot \mathrm{K}\right]^{+}$ KOTf

0 equiv. 106 min

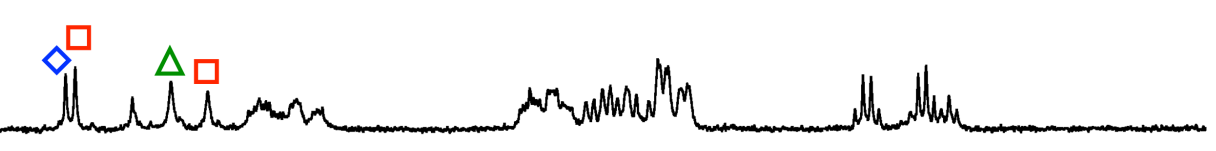

1.0 equiv. $23 \mathrm{~min}$

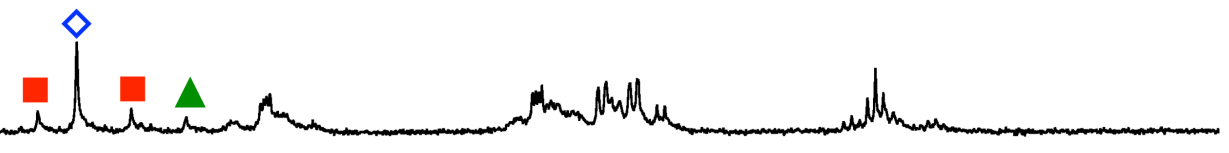

2.0 equiv. $19 \mathrm{~min}$

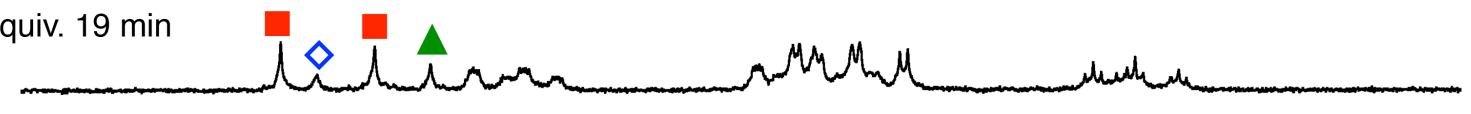

10 equiv. $12 \mathrm{~min}$

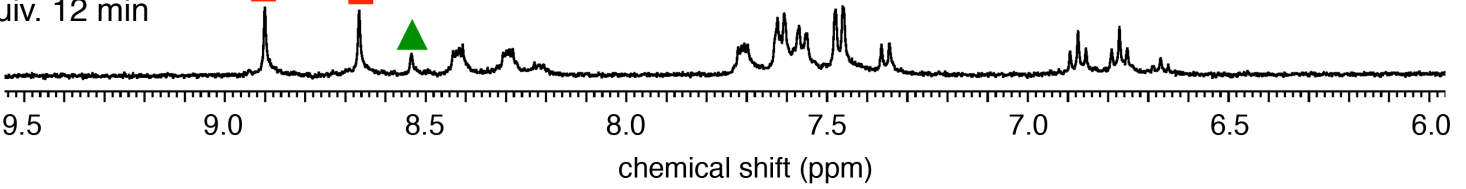

Figure S9. Comparison of ${ }^{1} \mathrm{H}$ NMR spectra of the mono-substituted complexes in the absence/presence of KOTf.

S14 


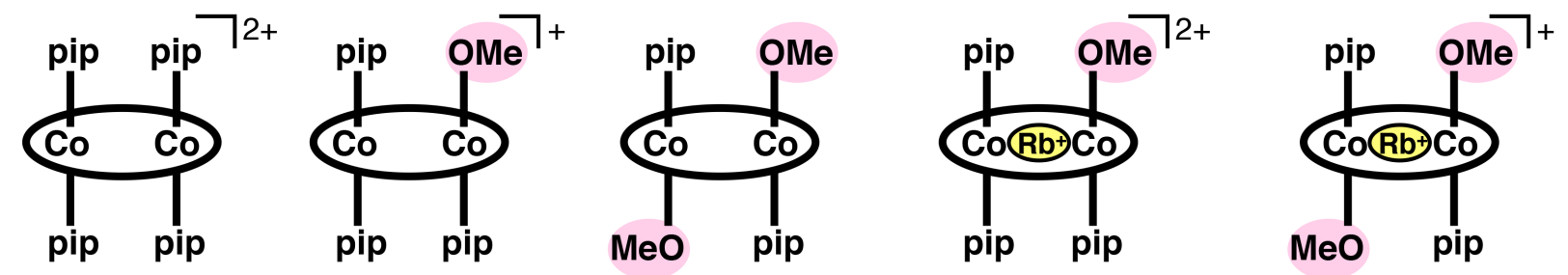

$\diamond\left[\mathrm{LCO}_{2}(\mathrm{pip})_{4}\right]^{2+} \quad \square\left[\mathrm{LCO}_{2}(\mathrm{pip})_{3}(\mathrm{OMe})\right]^{+} \Delta\left[\mathrm{LCO}_{2}(\mathrm{pip})_{2}(\mathrm{OMe})_{2}\right] \quad \square\left[\mathrm{LCo}_{2}(\mathrm{pip})_{3}(\mathrm{OMe}) \cdot \mathrm{Rb}\right]^{2+} \Delta\left[\mathrm{LCo}_{2}(\mathrm{pip})_{2}(\mathrm{OMe})_{2} \cdot \mathrm{Rb}\right]^{+}$ RbOTf

0 equiv. $106 \mathrm{~min}$

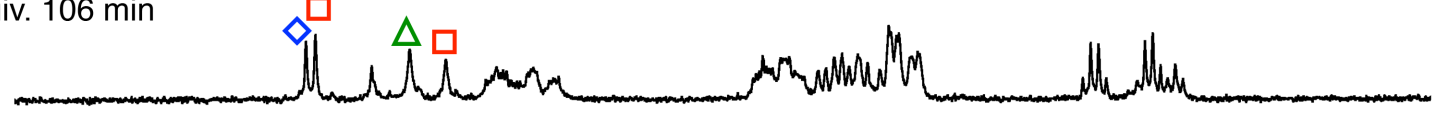

1.0 equiv. $76 \mathrm{~min}$

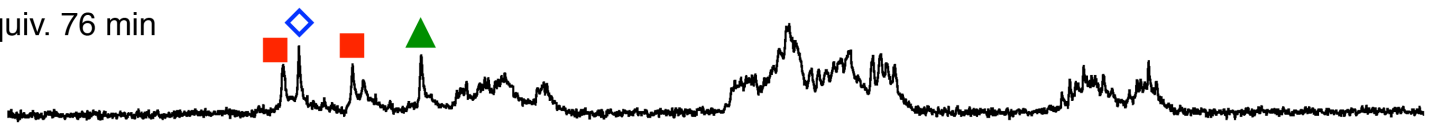

2.0 equiv. $53 \mathrm{~min}$

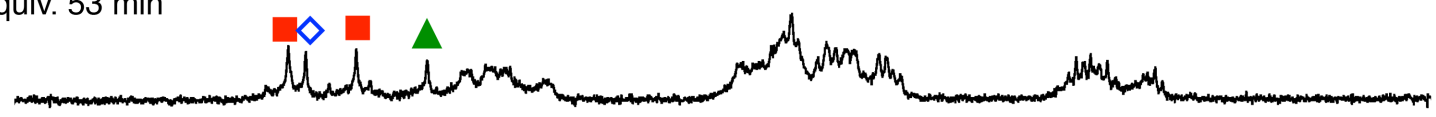

10 equiv. $32 \mathrm{~min}$

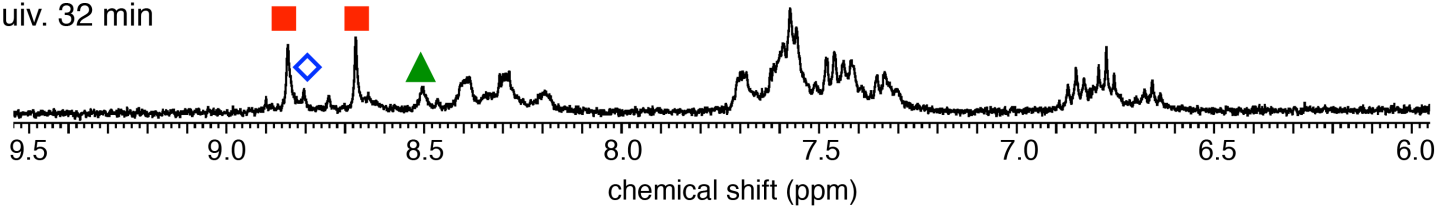

Figure S10. Comparison of ${ }^{1} \mathrm{H}$ NMR spectra of the mono-substituted complexes in the absence/presence of RbOTf. 

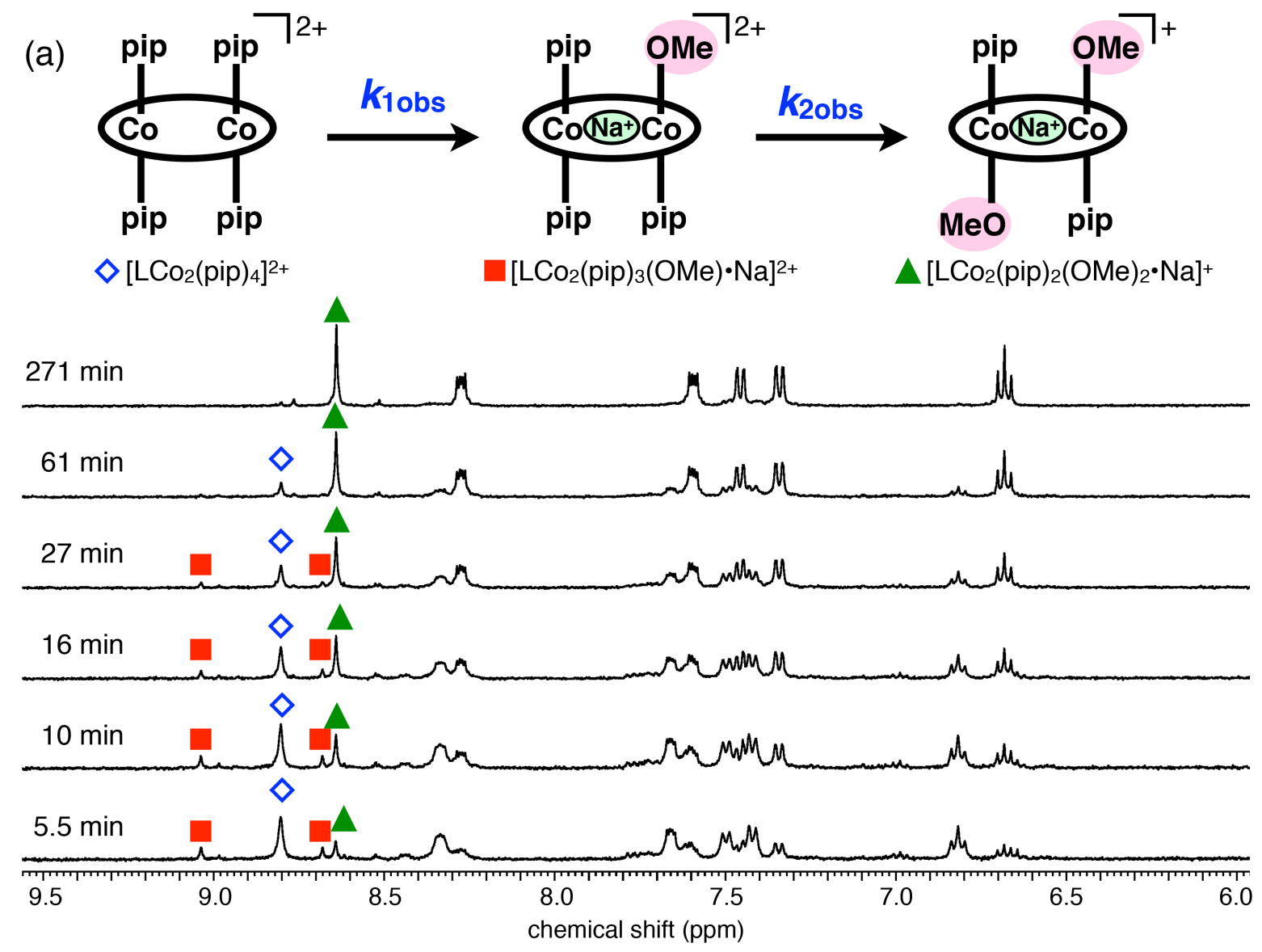

(b)

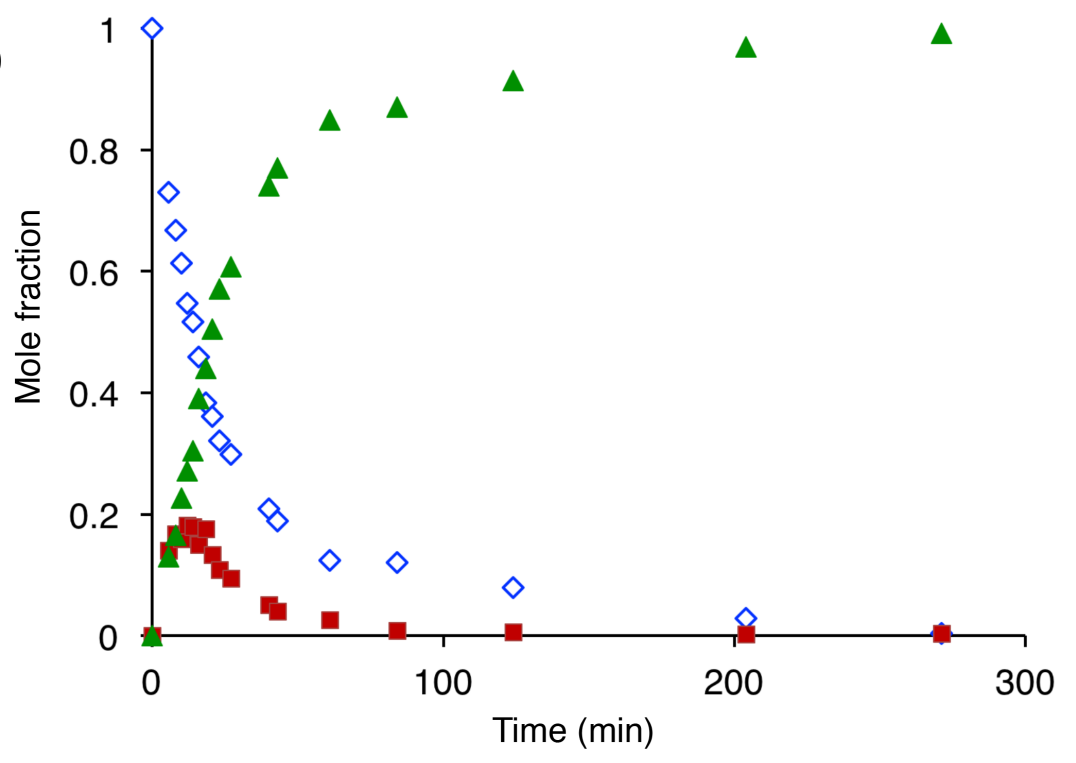

Figure S11. Time-course analysis of ligand exchange of piperidine with methoxo ligands in the presence of 1 equiv of NaOTf. (a) ${ }^{1} \mathrm{H}$ NMR spectral changes (imine and aromatic protons) in the presence of 1 equiv of NaOTf (blue diamonds, $\left[\mathrm{LCo}_{2}(\text { pip })_{4}\right]^{2+}$; red squares, $\left[\mathrm{LCo}_{2}(\text { pip })_{3}(\mathrm{OMe}) \cdot \mathrm{Na}\right]^{2+}$; green triangles, $\left.\left[\mathrm{LCo}_{2}(\text { pip })_{2}(\mathrm{OMe})_{2} \bullet \mathrm{Na}\right]^{+}\right)$. (b) Plots of the mole fractions of the three components versus time after dissolution in $\mathrm{CD}_{3} \mathrm{OD}$. 
(a)
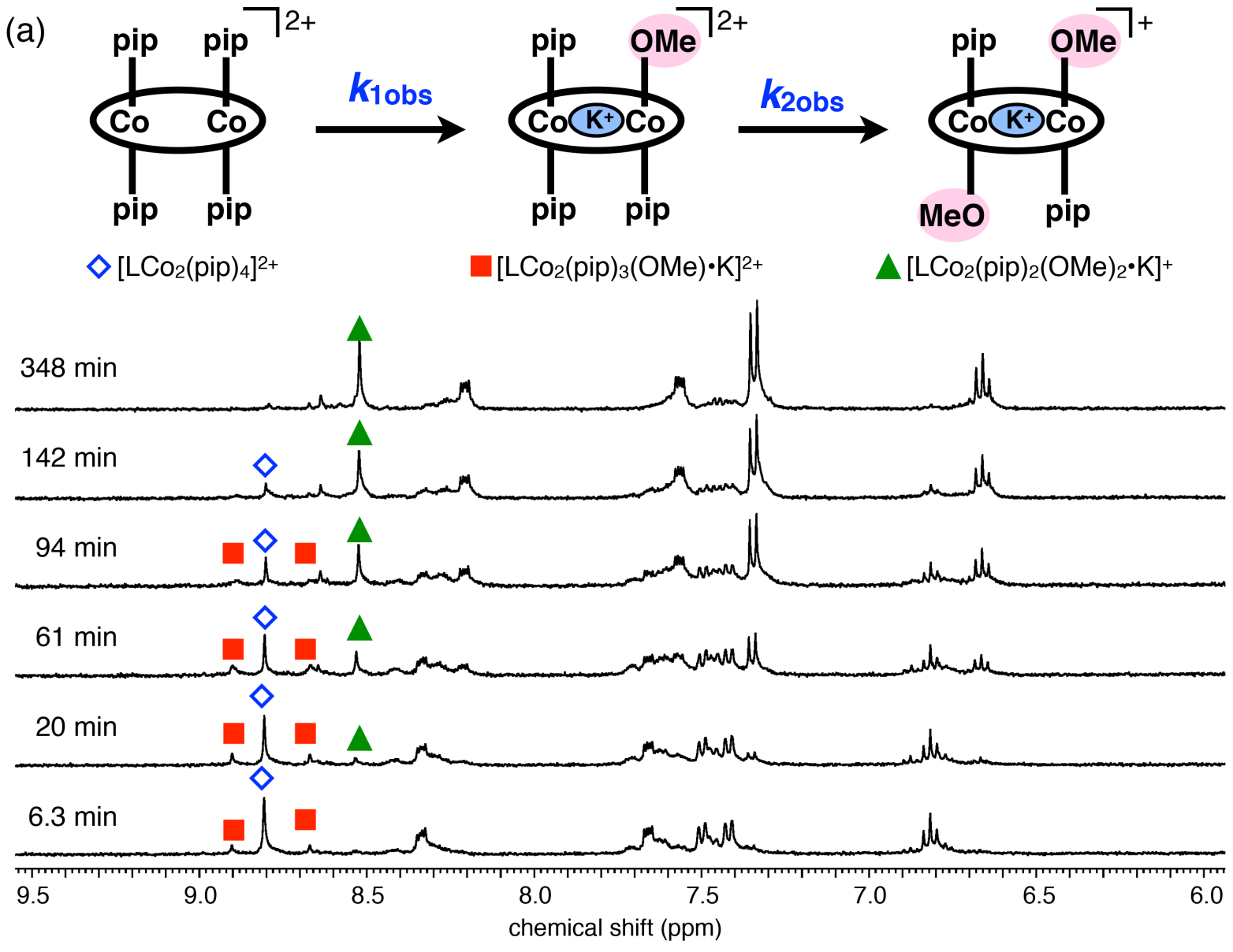

(b)

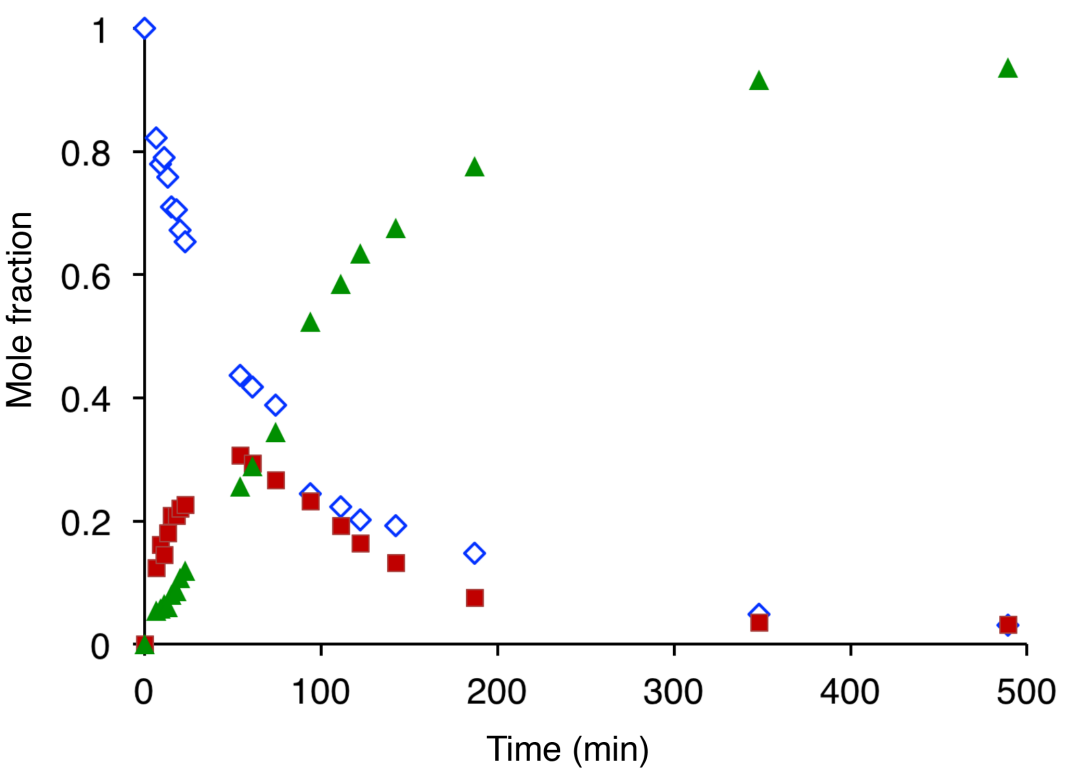

Figure S12. Time-course analysis of ligand exchange of piperidine with methoxo ligands in the presence of 1 equiv of KOTf. (a) ${ }^{1} \mathrm{H}$ NMR spectral changes (imine and aromatic protons) in the presence of 1 equiv of KOTf (blue diamonds, $\left[\mathrm{LCo}_{2}(\text { pip })_{4}\right]^{2+}$; red squares, $\left[\mathrm{LCo}_{2}(\text { pip })_{3}(\mathrm{OMe}) \cdot \mathrm{K}\right]^{2+}$; green triangles, $\left.\left[\mathrm{LCo}_{2}(\text { pip })_{2}(\mathrm{OMe})_{2} \bullet \mathrm{K}\right]^{+}\right)$. (b) Plots of the mole fractions of the three components versus time after dissolution in $\mathrm{CD}_{3} \mathrm{OD}$. 

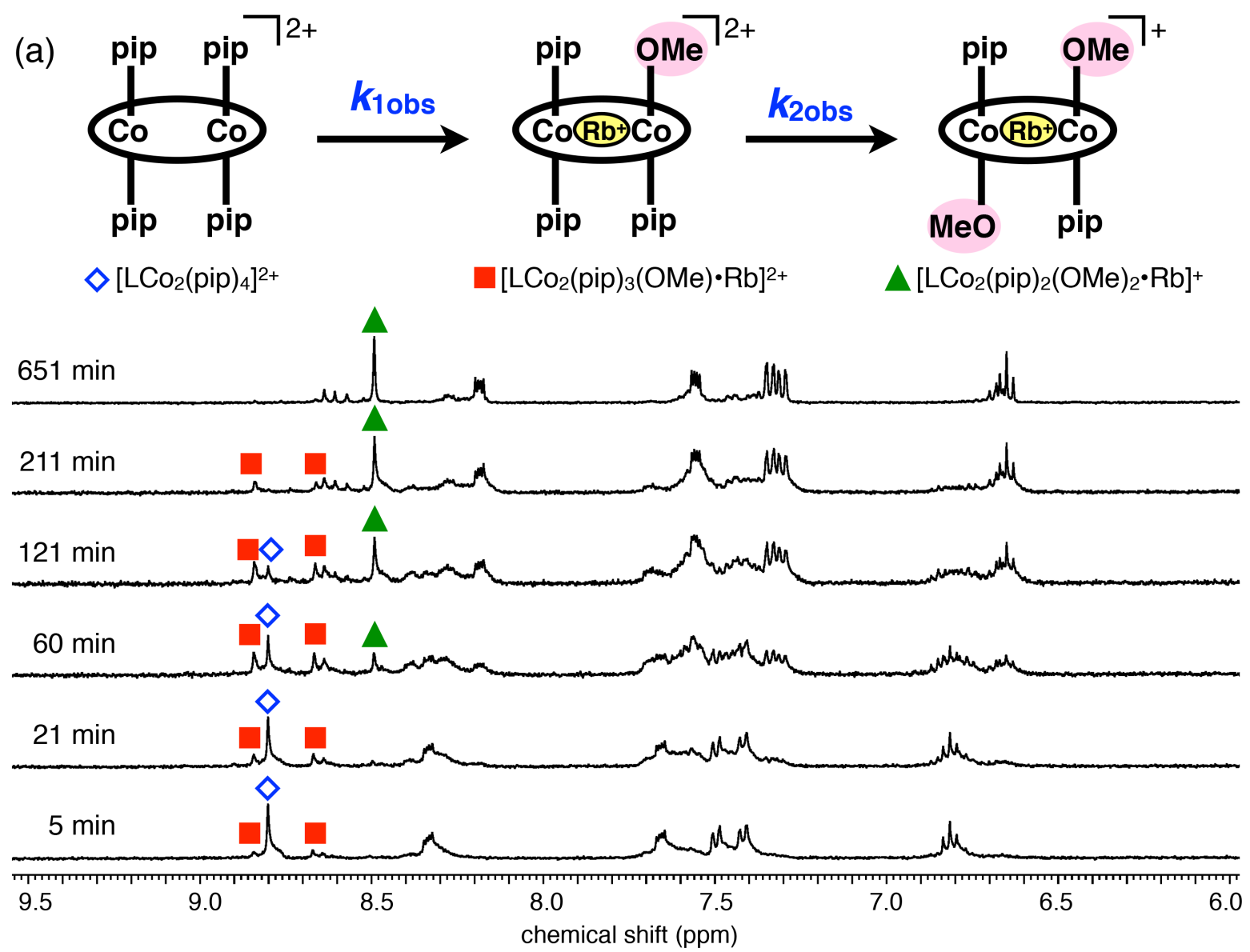

(b)

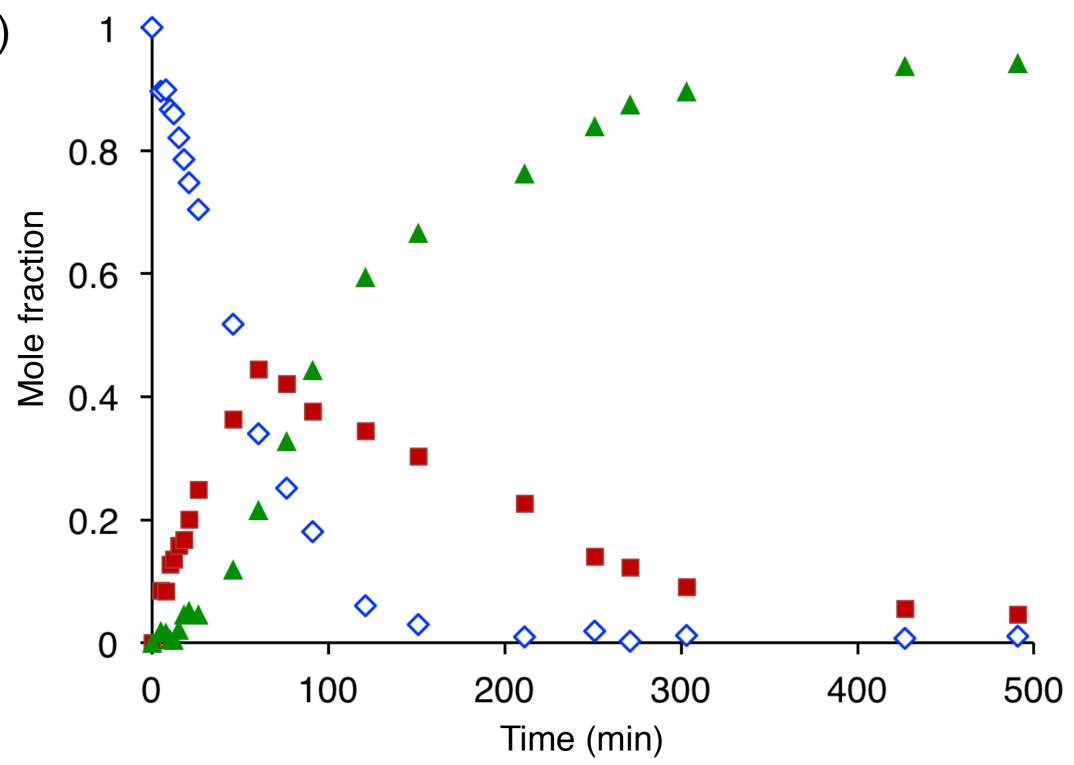

Figure S13. Time-course analysis of ligand exchange of piperidine with methoxo ligands in the presence of 1 equiv of RbOTf. (a) ${ }^{1} \mathrm{H}$ NMR spectral changes (imine and aromatic protons) in the presence of 1 equiv of RbOTf (blue diamonds, $\left[\mathrm{LCo}_{2}(\text { pip })_{4}\right]^{2+}$; red squares, $\left[\mathrm{LCo}_{2}(\text { pip })_{3}(\mathrm{OMe}) \cdot \mathrm{Rb}\right]^{2+}$; green triangles, $\left.\left[\mathrm{LCO}_{2}(\text { pip })_{2}(\mathrm{OMe})_{2} \cdot \mathrm{Rb}\right]^{+}\right)$. (b) Plots of mole fractions of the three components versus time after dissolution in $\mathrm{CD}_{3} \mathrm{OD}$. 

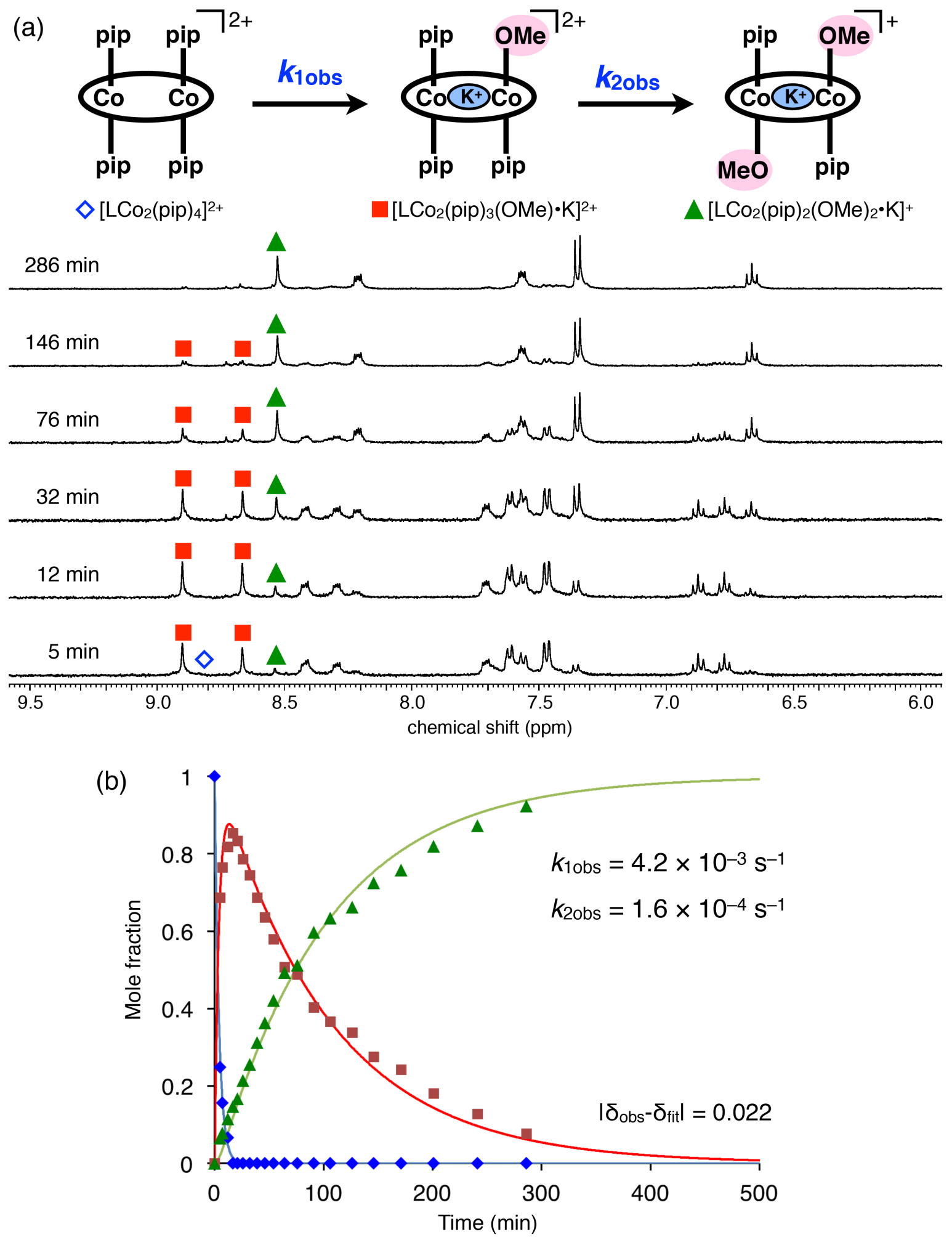

Figure S14. Time-course analysis of ligand exchange of piperidine with methoxo ligands in the presence of 10 equiv of KOTf. (a) ${ }^{1} \mathrm{H}$ NMR spectral changes (imine and aromatic protons) in the presence of 10 equiv of KOTf (blue diamonds, $\left[\mathrm{LCo}_{2}(\text { pip })_{4}\right]^{2+}$; red squares, $\left[\mathrm{LCo}_{2}(\text { pip })_{3}(\mathrm{OMe}) \cdot \mathrm{K}\right]^{2+} ;$ green triangles, $\left.\left[\mathrm{LCo}_{2}(\text { pip })_{2}(\mathrm{OMe})_{2} \bullet \mathrm{K}\right]^{+}\right)$. (b) Plots of the mole fractions of the three components versus time after dissolution in $\mathrm{CD}_{3} \mathrm{OD}$. 

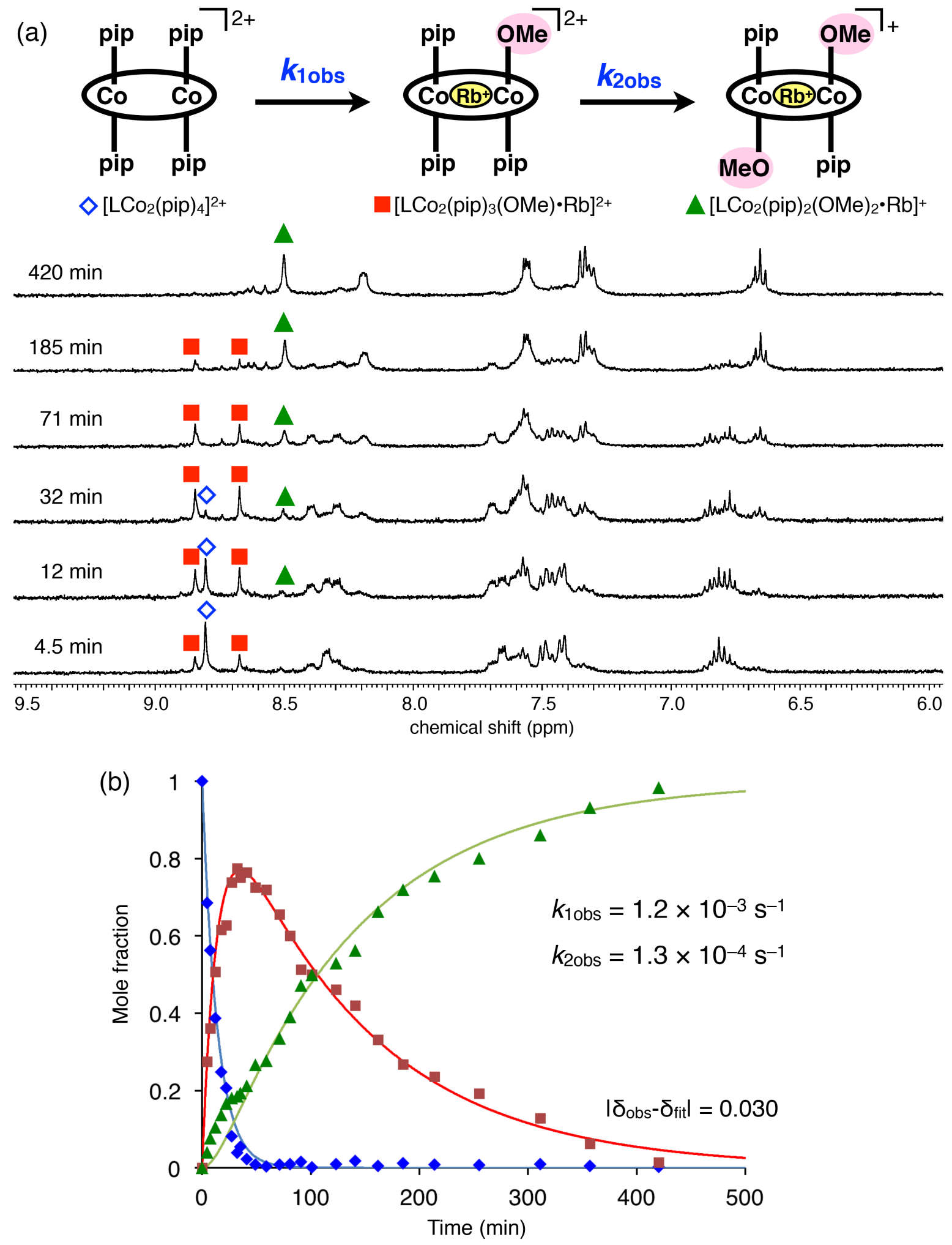

Figure S15. Time-course analysis of ligand exchange of piperidine with methoxo ligands in the presence of 10 equiv of RbOTf. (a) ${ }^{1} \mathrm{H}$ NMR spectral changes (imine and aromatic protons) in the presence of 10 equiv of RbOTf (blue diamonds, $\left[\mathrm{LCo}_{2}(\mathrm{pip})_{4}\right]^{2+}$; red squares, $\left[\mathrm{LCo}_{2}(\mathrm{pip})_{3}(\mathrm{OMe}) \cdot \mathrm{Rb}\right]^{2+}$; green triangles, $\left.\left[\mathrm{LCo}_{2}(\text { pip })_{2}(\mathrm{OMe})_{2} \bullet \mathrm{Rb}\right]^{+}\right)$. (b) Plots of the mole fractions of the three components versus time after dissolution in $\mathrm{CD}_{3} \mathrm{OD}$. 


\section{References}

[1] Sheldrick, G. M. SHELXT - Integrated space-group and crystal-structure determination. Acta Crystallogr. 2015, A71, 3-8.

[2] Sheldrick, G. M. Crystal structure refinement with SHELXL. Acta Crystallogr. 2015, C71, 3-8.

[3] Akine, S.; Utsuno, F.; Nabeshima, T. Highly efficient regulation of cation recognition and promotion of self-assembly by metalation of a macrocyclic bis $\left(\mathrm{N}_{2} \mathrm{O}_{2}\right)$ ligand with nickel(II). Chem. Commun. 2010, 46, 1029-1031. 